\title{
The Effectiveness of Endomycorrhiza Species on the Growth of Barangan Banana Seedlings
}

\author{
Asmah Indrawati ${ }^{1}$, Suswati ${ }^{2}$ \\ ${ }^{1,2}$ Medan Area University,Medan, Indonesia \\ suswati@uma.ac.id
}

\begin{abstract}
Utilization of various species of arbuscular mycorrhizal fungi in Barangan banana nurseries has been carried out in a wire house. The aim of the study was to obtain data on the effectiveness of Barangan banana seedling growth after various FMA species were applied. This research was conducted with a Completely Randomized Design with mycorrhizal (A) treatment consisting of 4 levels, namely: A0. Without mycorrhizae, A1. Glomus type 1; A2. Acaulospora type 4 and A3. Glomus fasciculatum (FMA isolate collection of Prof. Dr. Ir. Eti Farda Husin, MS) with 5 replications. A total of $10 \mathrm{~g}$ of FMA inoculants were separately put into the acclimatization media of the Barangan plantlet in the form of a sterilized charcoal and sand mixture (2: 1). during acclimatization. The results of this study indicate that seedling growth is better in the treatment of FMA applications than in controls. Acaulospora type-4 FMA isolates; Glomus type-1 and G. fasciculatum can increase the height of Barangan banana seedlings at a rate of: $3.117 \% ; 2,831 \%$ and 2,328\% while the rate of leaf growth is better in Glomus type-1 applications (1,865\%), G. fasciculatum (1,709\%) and Acaulospora type 4 $(1,412$ and control $(1,174 \%)$.
\end{abstract}

Keyword: Plantlet; Barangan banana; plant heigh; number of leaves; Glomus type 1; Glomus fasciculatum; Acaulospora type 4.

\section{Introduction}

Barangan Banana or better known as Medan Banana is a type of table banana that is very popular with the people of North Sumatra. The color of the flesh of the fruit is orange, tastes sweet and has a soft texture. This type of banana is widely developed in the Sub-District of Sinembah Tanjung Muda STM Hulu and STM Hilir, Deli Serdang Regency, North Sumatra Province.

According to data from the Central Statistics Agency of North Sumatra (2012) barangan banana production reached 15,793 tons with an area of 13,787 ha, or production / ha of 11.46 $\mathrm{kw}$ ha-1. Barangan fruit production is still relatively low when compared to the potential production of Barangan genetically. In ideal conditions, Barangan banana plants can produce as many as 198-220 kw ha-1 (planting distance of $3 \mathrm{mx} 3 \mathrm{~m}$, population of 1100 plants per ha).

One of the causes of the low production of Barangan in the North Sumatra Barangan banana planting center is the high attack of wilted fungi by Fusarium oxysporum $f$ sp cubense. This pathogen causes fusarium wilt disease which can reduce the yield of Barangan banana by 20-80\% (Nasir and Jumjunidang, 2003). Barangan bananas are classified as susceptible to F. oxysporum $f$ sp cubense. Fungi F.oxysporum $f$ sp cubense can attack all phases of the development of banana plants, from seedlings to fruiting plants. This fungus can survive 2040 years in the soil without any host plants in the form of Clamidospores. Clamidospores can survive in the soil of former dead host plants even without suitable host plants (Nelson, 1993).

One way to improve the resistance of Barangan seedlings to F.oxysporum $f$ sp cubense by application of inoculant arbuscular mycorrhizal fungi (FMA) indigenus. The inoculant used is an inoculant consortium of the genus Glomus and the genus Acaulospora derived from Rhizosphere of the banana plant of Kepok from Baso District, Agam Regency, West Sumatra. The application of FMA during acclimation can increase the micro propagation growth of 
Cavendish banana pantlet (Musa acuminata Colla AAA) (Ariningsih, 2009) causing better vegetative growth improvement in acid soil. In vitro application of Glomus intraradices can increase growth and availability of $\mathrm{P}$ to banana micro propagation (Musa spp. Cv. Grand Naine) (Declerck et al., 2000). According to Haryanti and Santoso (2000), the growth of red chili which was given mycorrhizal fungi was better than the red chili plant without FMA on the growth variables, namely plant height, leaf area, crown dry weight, number of fruits, and fruit weight. This is due to an increase in available $\mathrm{P}$ followed by an increase in the absorption of other elements, so that plant growth for the better.

Until now information about the growth of Barangan banana seeds after the application of various FMA genera is still limited and research has been conducted aimed to determine the effect of the application of FMA doses on the growth of Barangan plants in the nursery phase.

\section{Material and Method}

This research was carried out in the Faculty of Agriculture experimental garden and the Laboratory of Agrotechnology study program, Medan Area University, starting from February to July 2018.

\subsection{Experimental design}

This research was conducted by an experimental method, using a Randomized Block Design (RCBD) with treatment factors for the type of arbuscular mycorrhizal fungi (A) with 4 levels and 3 replications namely: A0 = without the application of FMA; A1 = Glomus type 1; A2 = Acaulospora type 4; A3 = G. fasciculatum. The planting medium used is a mixture of soil with cow manure (3: 1).

\subsection{Barangan Banana Planlet Preparation, FMA Application and Banana Seed Planting.}

The banana plantlet used was Barangan cultivar which was the result of in vitro propagation from a private tissue culture company, Medan. Plantlet bananas removed from the bottle, washed with running water until the media so as not to stick, then dried. To stimulate the formation of roots, plantlet roots cut up $2 \mathrm{~cm}$ left. The Barangan plantlet is acclimatized on a mixture of husk charcoal media with sterile sand (2:1). The mixture is put into a $12 \times 15 \mathrm{~cm}$ polybag. The FMA application is concurrent with the acclimation of the plantlet according to treatment. The source of FMA inoculums used was in the form of a mixture of sand growing media containing spores, external hyphae and root pieces of corn plants that were colonized with FMA.

The FMA dose was applied according to the treatment. As many Inoculants were put into the planting hole about $5 \mathrm{~cm}$ deep then the FMA was sown into the planting hole, then put 1 $\mathrm{cm}$ thick planting media and the Barangan banana plantlet was planted then the planting hole containing the plantlet was compressed with a layer of planting media.

The middle part of the acclimation media (manure mixture: husk charcoal (1:3) from each $12 \times 15 \mathrm{~cm}$ size polybag made a hole as deep as $5 \mathrm{~cm}$ sprinkled with $50 \mathrm{~g}$ of FMA inoculants containing about 100 spores, covered with a layer of soil $(2 \mathrm{~cm})$ then plantlets are planted. The pot is placed on a wooden shelf, to keep it moist; the seeds are covered with transparent plastic with $60 \%$ lighting.

14-day-old banana seedlings are transferred into a 30x40 cm polybag containing $8 \mathrm{~kg}$ of BDB-contaminated soil mixture and manure (3:1). At the same time fertilization is carried out 
with Urea, NPK and $\mathrm{KCl}$. Fertilization is done once a month with a $25 \%$ recommended dose. For 1 ha of bananas requires $207 \mathrm{~kg}$ of urea, $138 \mathrm{~kg}$ of super phosphate and $608 \mathrm{~kg}$ of $\mathrm{KCl}$ (Subakti and Supriyanto, 1996). Watering the seeds every day with $200 \mathrm{ml}$ of tap water. Weeding and pest control is done mechanically.

\subsection{Observation.}

Observations were made on plant height, number of leaves, dry weight of seedlings, and mycorrhizal colonization. The effectiveness of symbiosis / Relative mycorrhizal dependency (RMD) between FMA and banana plants can be calculated based on the formula Munyanziza et al. 1997; Brundrett, 1999):

$$
\begin{aligned}
& \text { RMD }=(\text { BKM }- \text { BKTM })(B K M)-1 \times 100 \% \\
& \text { BKM = dry weight of plants inoculated with FMA } \\
& \text { BKTM = dry weight of plants not inoculated with FMA }
\end{aligned}
$$

\section{Results and Discussion}

Plant height was used as an indicator of the effectiveness of FMA isolates performance. All FMA isolates can increase the height of Barangan banana seedling plants and statistically significantly different from control. The three FMA isolates have a high ability to increase the rate of increase in plant height and number of leaves ( $\mathrm{R} 2 \geq 0.97)$ (Table 1 and Figure 1). Glomus type- 1 best increases the height of the Barangan banana plant. At 7 days after acclimatization (hsa) height and number of plant leaves were not significantly different between the three FMA isolates, but were significantly different from controls (without FMA), as the age of Golmus type-1 isolates showed a higher ability, followed by Acaulospora type-4 and G. fasciculatum.

Table 1. Average Height of Barangan Banana Plant introduced by FMA Indigenous.

\begin{tabular}{lllllllll}
\hline The average height of Barangan banana plants in.... (days after planting) \\
\hline FMA Indigenous. & 7 & 14 & 21 & 28 & 35 & 42 & 49 & 56 \\
\hline Glomus type 1 & $6.67 \mathrm{a}$ & $9.10 \mathrm{a}$ & $11.27 \mathrm{a}$ & $14.27 \mathrm{a}$ & $16.76 \mathrm{a}$ & $20.10 \mathrm{a}$ & $22.87 \mathrm{~b}$ & $26.67 \mathrm{a}$ \\
Acaulospora tipe 4 & $7.00 \mathrm{a}$ & $8.93 \mathrm{a}$ & $10.87 \mathrm{a}$ & $12.76 \mathrm{~b}$ & $15.06 \mathrm{~b}$ & $17.57 \mathrm{~b}$ & $27.76 \mathrm{a}$ & $27.76 \mathrm{a}$ \\
G. fasciculatum & $6.00 \mathrm{a}$ & $7.93 \mathrm{~b}$ & $10.60 \mathrm{~b}$ & $12.80 \mathrm{~b}$ & $15.20 \mathrm{~b}$ & $17.46 \mathrm{~b}$ & $19.63 \mathrm{bc}$ & $22.30 \mathrm{~b}$ \\
Control & $6.03 \mathrm{a}$ & $7.96 \mathrm{~b}$ & $9.50 \mathrm{~b}$ & $10.73 \mathrm{c}$ & $11.23 \mathrm{c}$ & $12.37 \mathrm{c}$ & $13.57 \mathrm{c}$ & $15.60 \mathrm{c}$ \\
\hline
\end{tabular}

Acaulospora type 4 isolates had the highest ability in increasing the height of Barangan banana seedlings followed by Glomus type-1 and G. fasciculatum at a rate of $3.117 \% ; 2,831 \%$ and $2,328 \%$ (Table 2). For the number of leaves the Glomus type 1 isolate application was able to increase the highest number of leaves with a rate of increasing the number of leaves per week by $1,865 \%$ followed by G.fasciculatum isolates (1,709\%), Acaulospora type 4 by $1,412 \%$ and the lowest leaf growth rate was found in seedlings that were not applied with FMA (control).

Table 2. The rate of height increase of Barangan FMA banana seedlings at the age of 14 HSA

\begin{tabular}{l|ll}
\hline \multirow{2}{*}{ FMA } & Average height & \\
\cline { 2 - 3 } & Regression Equation & $\mathrm{R} 2$ \\
\hline Glomus type 1 & $\mathrm{y}=2.831 \mathrm{x}+3.222$ & 0.99 \\
Acaulospora type 4 & $\mathrm{y}=3.117 \mathrm{x}+1.935$ & 0.98 \\
G. fasciculatum & $\mathrm{y}=2.328 \mathrm{x}+3.512$ & 0.99 \\
Control & $\mathrm{y}=1.239 \mathrm{x}+5.294$ & 0.91 \\
\hline
\end{tabular}




\subsection{Number of Leaves}

The introduction of FMA influences the number of Barangan banana seedling leaves at 14 days after acclimatization (hsa) (Table 3). As bananas grow older, Glomus type-1 and G. fasciculate isolates showed almost the same ability with rates of $1,865 \%$ and $1,709 \%$, respectively (Table 2 and Figure 3), while Acaulospora type-4 was lower at 1,412\% and control of only 1,174 .

Table 3. Average number of Barangan banana seedling leaves introduced by FMA indigenus

\begin{tabular}{lllllllll}
\hline \multicolumn{7}{l}{ The average number of leaves of Barangan banana in age (days) } \\
\hline FMA & 7 & 14 & 21 & 28 & 35 & 42 & 49 & 56 \\
Glomus type 1 & $3.33 \mathrm{a}$ & $4.67 \mathrm{a}$ & $5.67 \mathrm{~b}$ & $7.67 \mathrm{ab}$ & $9.67 \mathrm{ab}$ & $11.00 \mathrm{a}$ & $14.67 \mathrm{a}$ & $16.00 \mathrm{a}$ \\
Acaulospora type 4 & $3.67 \mathrm{a}$ & $4.67 \mathrm{a}$ & $5.67 \mathrm{~b}$ & $7.33 \mathrm{a}$ & $8.33 \mathrm{~b}$ & $9.67 \mathrm{~b}$ & $11.33 \mathrm{~b}$ & $14.00 \mathrm{a}$ \\
G. fasciculatum & $3.33 \mathrm{a}$ & $4.33 \mathrm{a}$ & $6.33 \mathrm{a}$ & $8.33 \mathrm{a}$ & $11.00 \mathrm{a}$ & $12.30 \mathrm{a}$ & $14.00 \mathrm{a}$ & $15.00 \mathrm{a}$ \\
Control & $3.00 \mathrm{a}$ & $3.33 \mathrm{~b}$ & $4.33 \mathrm{c}$ & $6.00 \mathrm{~b}$ & $8.33 \mathrm{~b}$ & $9.33 \mathrm{c}$ & $9.33 \mathrm{c}$ & $10.33 \mathrm{c}$ \\
\hline
\end{tabular}

Table 4. Rate of increase in number of Barangan FMA banana seedlings at the age of 14 HSA

\begin{tabular}{lll}
\hline FMA & \multicolumn{2}{l}{$\begin{array}{l}\text { The average number of leaves of Barangan } \\
\text { seedlings }\end{array}$} \\
\cline { 2 - 3 } & Regression Equation & $\mathrm{R} 2$ \\
\hline Glomus type 1 & $\mathrm{y}=2.831 \mathrm{x}+3.222$ & 0.99 \\
Acaulospora type 4 & $\mathrm{y}=3.117 \mathrm{x}+1.935$ & 0.98 \\
G. fasciculatum & $\mathrm{y}=2.328 \mathrm{x}+3.512$ & 0.99 \\
Control & $\mathrm{y}=1.239 \mathrm{x}+5.294$ & 0.91 \\
\hline
\end{tabular}

There were generally all FMA isolates used significantly able to increase the dry weight of Barangan banana plants. The highest dry weight was obtained in the Glomus type-1 treatment that was $53.10 \mathrm{~g}$, followed by G. fasciculatum $33.67 \mathrm{~g}$; Acaulospora type-4 was 22.96 $\mathrm{g}$ while the control was only $8.51 \mathrm{~g}$.

The difference in effectiveness of mycorrhizal isolates is strongly influenced by the type of FMA given, the age of the plant at the time of introduction of the FMA, the type of plant and other supporting environmental factors. Introducing FMA at the time of acclimatization will more quickly colonize roots compared to further age. Besides the difference in effectiveness is due to differences in the ability of each isolate in symbiosis with banana seedlings roots. It is possible that each isolate has a different preference for the exudates released by the banana seedlings.

\subsection{Colonization of arbuscular mycorrhizal fungi.}

Improvements in various parameters of plant growth were due to the better development of the root system which was colonized by the FMA. In general the percentage of mycorrhizal colonization is found in seedlings aged 30 hsa and increases with age of seedlings (Table 4). Mycorrhizal colonization can be observed by staining the roots of banana seeds with Fuchsin acid techniques (Sukarno, 1998) and calculated with the formula Kormanick et al. (1980). The structure of external hyphae that colonize roots will increase exploration ability 5-200 times compared without mycorrhizae (Sieverding, 1991). External FMA hyphae with a diameter of $10 \mu \mathrm{m}$ will be more effective in absorbing nutrients and water than roots (diameter $>300 \mu \mathrm{m}$ ). 
Table 4. Percentage, intensity and effectiveness of colonization and density of Barangan seedling spores at the age of 30 hsa and 60 has

\begin{tabular}{|l|l|l|l|l|l|l|l|l|}
\hline & \multicolumn{9}{|c|}{ FMA colonization and spora density } \\
\hline & \multicolumn{3}{|c|}{ 30 dap } & \multicolumn{4}{c|}{ 60 dap } \\
\hline Treatment & CP & ES & IC & EC & CP & ES & IC & EC \\
\hline Glomus tipe 1 & 35 & 85.71 & 2 & 90 & 80 & 1.25 & 4 & 132 \\
\hline Acaulospora tipe 4 & 25 & 80.00 & 2 & 75 & 80 & 91.25 & 4 & 129 \\
\hline G. fasciculatum & 25 & 80.00 & 2 & 25 & 70 & 0.00 & 4 & 48 \\
\hline Kontrol & 5 & 0.00 & 2 & 5 & 7 & 0.00 & 2 & 12 \\
\hline
\end{tabular}

$\mathrm{CP}^{*}=$ colonization percentage, $\mathrm{IC}=$ Intencity colonization, $\mathrm{SD}=$ spora density per $10 \mathrm{~g}$, $\mathrm{ES}=$ efectifitas simbiosis

Microscopically it was observed that the genus Glomus had high colonization ability in the Barangan banana plant followed by the genus Acaulospora type 4. This was supported by the fact in the field that in general the Glomus genus could colonize various types of bananas. According to Mosse (1981), the genus Glomus had a distribution, the broadest range of plants and host plants among other genera.

In addition the difference in effectiveness is due to differences in the ability of each isolate in symbiosis with banana seedlings roots. It is possible that each isolate has a different preference for the exudates released by the banana seedlings. According to Singh et al. (2000); Azcón-Aguilar et al. (2002); Xavier and Boyetchko (2004), the success of introducing FMA in increasing plant growth will be determined by various factors including the type of FMA, the rate of colonization of the FMA, the sequence of introduction, the plant growth phase and the type of host plant.

\subsection{Plant dry weight}

Dry weight is the nutritional status of plants, which is a good indicator of plant growth which is closely related to nutrient availability. On the other hand also illustrates the ability of plants to take nutrients contained in plant growth media. The highest dry weight was found in Barangan banana seedlings with Glomus type 1 application of $53.1 \mathrm{~g}$ followed by isolates $\mathrm{G}$. fasciculatum (33.67 g), Acaulospora type 4 (22.96 g) and control (8.51 g) (Table 5). This was also in line with height Relative mycorrhizal dependency level of Barangan seedlings to the isolate of the genus Glomus compared to the genus Acaulospora.

Table 5. Dry weight of Barangan banana seedlings with the application of various mycorrhizal isolates

\begin{tabular}{lll}
\hline FMA & Dry weight $(\mathrm{g})$ & Relative mycorrhizal dependency \\
\hline Glomus type 1 & $53.10 \mathrm{a}$ & 83.97 \\
Acaulospora type 4 & $22.96 \mathrm{c}$ & 62.93 \\
G. fasciculatum & $33.67 \mathrm{~b}$ & 74.72 \\
Control & $8.51 \mathrm{~d}$ & - \\
\hline
\end{tabular}

The effectiveness of symbiosis is reflected in increased growth and yield of plants. In general, the effectiveness of FMA symbiosis with banana plants is relatively high. The difference in the ability of FMA in increasing plant growth is due to differences in FMA ability to colonize roots and differences in nutrient and water absorption. According to Camprubi and 
Calve, (1996), the ability of FMA to support root growth and colonization, varies depending on the suitability of the combination of fungi and hosts. Mycorrhizal plants will absorb more nutrients and water than plants without the introduction of FMA. If the nutrients and water are met it will stimulate the photosynthetic activity and the resulting photosynthetic will be used for tissue growth including leaves, roots and stems (Morte et al., 2000). Besides the introduction of FMA can increase photosynthesis because FMA can increase leaf water potential, chlorophyll content so that the assimilation rate increases.

The difference in the ability of mycorrhizal isolates is strongly influenced by the type of FMA given, the age of the plant at the time of FMA introduction, the type of plant and other supporting environmental factors. Introducing FMA at the time of acclimatization will more quickly colonize roots compared to further age.

Mycorrhizal colonization in plant roots also causes an increase in the quality of the planting medium through an increase in the banana seed root exudates compounds. An increase in $\mathrm{pH}$ and content of various nutrients in banana growing media compared to before planting. Increased $\mathrm{pH}(\mathrm{H} 20)(23.98 \%)$, total $\mathrm{N}$ (131.58\%), available P (266.12\%), K (250.64\%), Corganic (129.64\%), Ca (129.90\%) and $\mathrm{Mg}(106.64 \%)$. From the data obtained it can be stated that the introduction of FMA alters the proportion of nutrients present in plants. This change in nutrient proportions can spur faster metabolic processes as indicated by an increase in biomass at the same time.

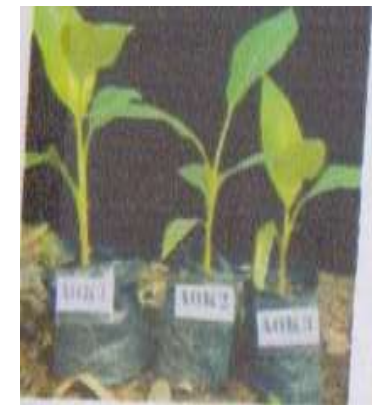

Figure 6. Barangan banana growth by introducing 3 types of FMA. Control A; A1.Glomus type-1; A2.Acaulospora type-4; A3. Glomus fasciculatum.

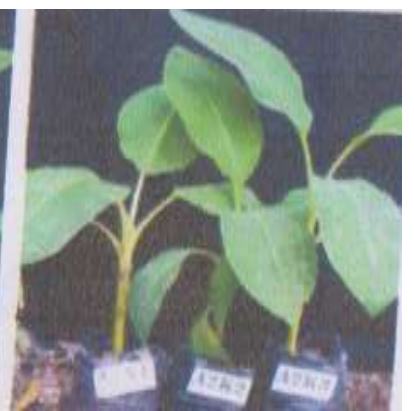

\section{Conclusion}

From the research activities, the following conclusions can be drawn:

1. Introduction of FMA (Glomus type-1, Acaulospora type-4, Glomus fasciculatum) is able to increase growth (height, number of leaves and stoves) of corn plants and Barangan banana seeds.

2. Roots of maize and Barangan banana plants can be colonized by 3 types of FMA observed from the high percentage and intensity of FMA colonization and the intensive mycorrhizal structure (spores, external hyphae and internal hyphae).

\section{References}

Ariningsih S. 2009. Penggunaan Beberapa Isolat Fungi Mikoriza Arbuskula (FMA) dalam Meningkatkan Ketahanan Bibit Pisang Kultivar Kepok terhadap Serangan Penyakit Darah (Blood Disease Bacterium). Skripsi Sarjana Biologi Universitas Andalas. Padang. 
Azcón-Aguilar C, Jaizme-Vega MC, \& Calvet C, 2002. The contribution of arbuscular in : Schuepp S, Haselwandter H, Barea JM, Birkhauser Verlag, Basel (eds.) Agriculture: from Genes to Bioproducts, Gianinazzi, Switzerland, pp. 187-197.

Badan Pusat Statistik Sumatera Utara (2012). https://sumut.bps.go.id/statictable/2017/11/17/749/produksi-buah-buahan-menurutjenis-tanaman-ton-2012---2016.html, accessed September 23, 2019

Brundrett MC, Abbott LK, Jasper DA (1999) Glomalean mycorrhizal fungi from tropical Australia. I. Comparison of the effectiveness and specificity of different isolation procedures. Mycorrhiza 8:305-314

Daryanto 2004. Laporan Perkembangan Penyakit Layu Pisang. Direktorat Perlindungan Tanaman Hortikultura, Agustus 2004.

Declerk S, Rufyikiri G, Dufey JE, \& Delvaux B. 2000. Arbuscular mycorrhizal fungi might alleviate aluminium toxicity in banana plants. New Phytopatol. 148 (2):343-352.

Haryanti, B. A. dan M. Santoso. 2000. Pertumbuhan dan Hasil Cabai Merah yang diberi Mikoriza, Pupuk Fosfor, dan Zat Pengatur Tumbuh.

http://digilib.brawijaya.ac.id.virtuallibrary/malang_warintek/pdf/ accessed Oktober 19, 2014.

Kormanick PP, Bryan WC, \& Schultz RC. 1980. Procedures and equipment for staining large number of plant roots for Endomycorrhizal assay.Can. J. Microbiol. 26:536-538.

Mosse B. 1981. Vesicular-Arbuscular Mycorrhiza Research for Tropical Agriculture. Hawaii Institute of Tropical Agriculture and Human resources, Univ. of Hawaii.

Morte A, Lovisolo C and Schubert A. 2000. Effect of drought stress on growth and water relations of mycorrhizal association Helianthum almeriense-Tervesia claveryi. Mycorriza J. 10(3):115-119

Munyanziza E., Kehri H.K. Bagyaraj D.J. 1997. Agricultural intensification, soil biodiversity and agroecosystem function in the tropics: the role of mycorrhiza in crops and trees. Applied Soil Ecology 6:77-85.

Nasir N \& Jumjunidang. 2003. Karakterisasi ras F.oxysporum f.sp. cubense dengan metode vegetative compatibility group test dan identifikasi kultivar pisang yang terserang. J.Hort., vol 13. no.4. pp.267-28

Nelson, P.E. 1993. Taxonomy of Fungi in the Genus Fusarium with Emphasis on Fusarium oxysporum.Fusarium Wilt of Banana. APS Press. The American Phytopathological Society, St. Paul, Minnesota.

Sieverding E. 1991. Vesicular- arbuscular mycorrhiza management in tropical agrosystems. GTZ GmbH. Germany. pp. 371.

Singh R, Adholeya A, \& Mukerji KG. 2000. Mycorrhiza in control of soil borne pathogens. In: Mukerji KG,Chamola BP, \& Snigh J. (eds.) Mycorrhizal biology. Kluwer Academic, New York, pp 173-196.

Subakti H \& Supriyanto B. 1996. Perbaikan tehnik budidaya pisang. Balitbangtan. Balai Penelitian Tanaman Buah. Solok

Xavier L \& Boyetchko S. 2004. Arbuscular mycorrhizal fungi in plant disease control. In: Arora D, Bridge P, Bhatnagar D. (eds.) Fungal Biotechnology in Agricultural, Food, and Environmental Applications. Marcel Dekker, Inc., New York 